\title{
25. Religion and the 2010 Election: Elephants in the room
}

\author{
John Warhurst
}

The 2010 Australian election continued a recent pattern in which religion has played a role in the campaign. This election continued some of the themes of recent elections such as Christian-Greens tensions, social morality and education politics, but with a new twist given the particular personal characteristics of the two major-party leaders: Julia Gillard, a declared atheist, and Tony Abbott, a conservative Catholic.

After the 2004 election campaign, prospective Labor leader, Kevin Rudd, concluded that the Coalition had captured the so-called 'religious vote'. This was a campaign conducted amid great publicity about the so-called 'Religious Right', the apparent rise of evangelical Christians, and the election of a Family First Senator, Steve Fielding. The established Christian churches, led by the Anglican and Catholic Archbishops of Melbourne and Sydney, had also campaigned against the education policies of Labor's agnostic leader, Mark Latham, apparently to great effect (Manning and Warhurst 2005). Rudd's subsequent project was to draw his party's attention to religious questions and to sell Labor's religious heritage and social gospel values to the electorate. It came to fruition in his article 'Faith in politics' for The Monthly magazine (Rudd 2006; reprinted in Macklin 2007).

The 2007 campaign saw this project in action (Warhurst 2010c). Rudd, an observant Anglican, attempted to sell his credentials to the evangelical constituency - in particular, through his participation alongside John Howard in the initial 'Making it Count' forum hosted by the Australian Christian Lobby (ACL). Here he combined personal social conservatism with socialjustice principles based upon Christian socialism. Opinions vary as to how successful Rudd's ploy was. Rodney Smith, in his study of the ACL campaign (Smith 2009), doubts that it was. Others, such as former senator John Black and columnist Christopher Pearson, conclude that social conservatives in the church communities were drawn to Rudd, who promised, among other policies, not to advance the cause of gay marriage (Australian Development Strategies 2008). Certainly, religious belief was a notable aspect of Rudd's persona, and attention to his beliefs and church attendance continued throughout his term in office (Warhurst 2010a). Labor had a leader regarded as perhaps the most publicly religious of any prime minister in Australian history (Stuart 2009). 
After Tony Abbott replaced Malcolm Turnbull as Opposition Leader in December 2009, he and Rudd were described as the most religious pair of leaders Australia had ever had (Young 2010). That was the state of play in the pre-campaign period when the ACL repeated its 'Make it Count' forum, held at Old Parliament House in Canberra, but also telecast to churches around Australia, on 21 June. This event-innovative in 2007-remains a notable part of the election campaign. Rudd and Abbott presented themselves as two pro-church leaders willing to endorse the ACL agenda on matters such as chaplains in schools, parliamentary prayers and opposition to gay marriage. Shortly afterwards, Rudd was deposed by Julia Gillard and this aspect of the election campaign was given a new twist.

\section{The Beliefs of the Leaders}

The two leaders offered a fascinating contrast in terms of religious beliefs. Arguably, they were both outside the Australian norm, despite a number of previous observant Christians and agnostics among previous prime ministers. Abbott's beliefs were always going to be an issue as his orthodox, conservative Catholicism had long attracted attention, especially the combination of his antiabortion advocacy and his position as Howard's Minister for Health (Gleeson 2010; Warhurst 2007). This had come to a head when a conscience vote of the Parliament had removed his responsibility for the abortion drug RU486, in 2006.

Abbott's supporters claimed then that he was a victim of anti-Catholic sectarianism, while his critics claimed he was unelectable because of his relative unpopularity among women. During the campaign, some media certainly presented him as defined by his religious beliefs. The Sydney Morning Herald election special on the morning after the election was called, for instance, featured him in a large front-page cartoon wearing a clerical collar (Sydney Morning Herald, 19 July 2010). Afterwards The Australian claimed that the negative 'Mad Monk' image had been greatly overdone in various media (The Australian 2010).

Gillard's religious beliefs had not attracted attention when she was Deputy Prime Minister, being greatly overshadowed by her gender. But soon after she became the first woman prime minister, in stark contrast with both Abbott and Rudd, she declared herself to be an atheist (not an agnostic) in an ABC interview with Jon Faine, while stressing her Baptist religious upbringing and her respect for believers (Burchell 2010; Mullins 2010a). Thereafter her unbelief became part of her public identity as religious leaders cautioned against a growth in secular beliefs in the community. It was also frequently linked-directly and indirectly — with her de-facto relationship with her partner, Tim Mathieson. 
The leaders themselves treaded cautiously and seemed not to wish to inflame the differences. Abbott was conciliatory (Sydney Morning Herald, 9 August 2010). ${ }^{1}$ He promised not to attempt to change abortion laws if elected. Gillard engaged fruitfully with Cardinal George Pell in a Saint Mary McKillop fundraiser (Mullins 2010a), and maintained Rudd's policy opposition to gay marriage (Stockman 2010). She later apparently satisfied the ACL's Jim Wallace during a catch-up recorded interview (Stephens 2010).

\section{Collective Church Lobbying}

The major churches, church agencies and para-church groups traditionally undertake campaign advocacy across an enormous range of issues. This campaign was no different. The Australian Catholic Bishops' Conference, for instance, issued a statement identifying six essential criteria, beginning with '[t]he right of every person to human dignity' and mentioning 11 particular issues (Australian Catholic Bishops' Conference 2010). ${ }^{2}$ The statement illustrates the frequent lack of focus in church statements, brought about by attempts to be inclusive of all religious points of view.

Particular church agencies and groups of agencies also entered the campaign. The social-justice agencies were unimpressed by both major parties on issues such as compassion for refugees and spending on foreign aid. Major church groups involved in social services called for greater investment in mental health. Various religious groups joined other groups in holding campaign meetings and hosting candidates' forums in local electorates (ACL, for instance, ran 20 such forums).

The ACL identified a range of concerns at the 'Making it Count' forum. These included seven topics covered in follow-up questions to each leader. These were: Indigenous affairs and the NT intervention, the continuation of parliamentary prayers, the treatment of asylum-seekers, the defence of traditional marriage and opposition to same-sex unions, the continuation of the school chaplaincy program, the alarming sexualisation of young girls, and climate change issues. Some of these questions would have graced any secular forum, while others clearly played to specialist church audiences.

\footnotetext{
1 A letter to the editor by M. Steffen noted Abbott's comments on ABC Radio the previous day: 'Just as my Catholicism should not be held against me, her views or lack of views on the subject should not be held against her [Gillard].'

2 The essential criteria were the right of every person to: human dignity; adequate food, shelter and protection; equality of access to education, health, employment and basic services; both present and future generations, to live in a safe, healthy and secure environment; and the duty to contribute to society to the extent that they are able; to live according to their own beliefs, to the extent that those beliefs do not impact upon the right of others. The issues were: health, social justice, migrants and refugees, overseas aid, women, Indigenous Australians, disability, the environment, education, religious liberty and human dignity.
} 
Very little of this collective church lobbying had a high profile in the mainstream media, though it was mentioned, so that any influence was probably restricted to narrower audiences, including regular churchgoers. Much of it was deliberately bland, balanced and non-provocative. But this was not the case for some individual interventions.

\section{Individual Church Lobbying}

Gillard's beliefs were attacked by several unknown or marginal religious figures, such as Danny Nalliah of Catch the Fire Ministries. But the two most senior individuals who intervened in the campaign were Catholic archbishops: Barrie Hickey of Perth and George Pell of Sydney.

Hickey's comments decrying the growth of secularism were given a frontpage headline ('Archbishop questions impact of Gillard's atheism') by the West Australian (29 July 2010). While he subsequently defended his comments as apolitical and misconstrued, they were certainly interpreted at the time as a veiled attack on Gillard and as being unhelpful to the Labor campaign. It drew an alternative view in The Australian by Anglican Archbishop of Perth, Roger Herft, that ethics were just as important as faith (CathNews 2010a).

Pell's initial comments were made in his regular column in The Sunday Telegraph and on the archdiocesan web site (8 August 2010). The main theme was a devastating attack on the Greens as 'anti-Christian'. He concluded that 'for those who value our present way of life, the Greens are sweet camouflaged poison'. Controversy followed. Bob Brown replied in equally provocative terms, questioning whether Pell represented mainstream Christianity (CathNews 2010b; Warhurst 2010a). Then an extensive online debate - some of it reported in the mainstream media-followed within the Catholic community. Some, such as Jesuit priest Frank Brennan and Catholic Social Services Australia's Frank Quinlan, attempted a conciliatory defence of the Greens (Brennan 2010; Quinlan 2010). Others, such as the Melbourne Director of Catholic Education, Steven Elder, claimed that support for the Greens was a vote against Catholic education (Elder 2010). The ACL supported Pell by uploading a second media release by the Sydney Catholic Archdiocese (9 August 2010). This bitter controversy had the potential to damage Greens support, especially in Sydney, where it contributed to a wider media attack on the Greens. 


\section{Secular Campaigning}

Secular lobby groups are weaker in comparison. There is also the problem of which ones to include in such a category. The Atheist Foundation predicted that Gillard's beliefs would not be an electoral negative, while the national coordinator of EMILY's List rebutted the suggestion that to be pro-choice on abortion was anti-Christian (Sharp 2010).

Two minor political parties, the Secular Party and especially the Australian Sex Party, were probably of greater importance in this regard than any lobby group. The latter, launched in 2008, was convened by experienced lobbyist Fiona Patten. It campaigned against censorship and the Internet filter with the slogan 'Keeping politicians out of the bedroom', and had at least two prominent media supporters in David Barnett and Ross Fitzgerald (Fitzgerald 2010). It regularly portrayed itself as an opponent of religious hypocrisy.

\section{Minor Religious Parties}

Several smaller minor parties that can be described either as religious or as having religious overtones also campaigned nationally. The reborn Democratic Labor Party (DLP), buoyed by winning a seat in the Victorian Legislative Council in 2006, emphasised pro-life and pro-family issues and had Senate aspirations in its historical stronghold in Victoria. Family First, associated with evangelical churches, was led by Steve Fielding, hoping for election for a second term in the Senate contest in Victoria. The Christian Democratic Party (CDP) led by Reverend Fred Nile held seats in the NSW Legislative Council and always attracted votes in that State.

\section{Impact on Voters}

The evidence is slender so far but what there is suggests that on balance Abbott's religion was more of a negative than Gillard's atheism. Even when compared with Rudd in an earlier study by Graham Young of online opinion, Abbott's religion bothered more voters because they thought he was inflexible in his beliefs (Young 2010). Yet the chapter by Bean and McAllister in this volume indicates that although the pattern was 'unusual' in Australian political history, Catholics were inclined towards the Coalition.

The Canberra Times-Patterson poll in the electorate of Eden-Monaro, subsequently held by Labor, concluded that the religious views of the leaders when it mattered slightly favoured Gillard (McLennan 2010). It calculated that 
the net pro-Labor influence was 12 per cent while the net pro-Liberal influence was 9 per cent. Women, those under thirty-five and Greens voters were three categories noticeably drawn to Labor because of the religious factor, while men and over thirty-fives were more evenly split in this survey.

\section{Conclusion}

In this campaign religious belief or the lack of it threatened to become a major political issue. It pitted two political leaders whose attitude to religious belief was both out of the ordinary and markedly different. Gillard's public atheism contrasted clearly with Abbott's public Catholicism.

There was a range of interesting religion-related campaign phenomena, beginning even before Gillard became Prime Minister. Religious groups were active, as were prominent individuals such as Cardinal Pell. The religious groups predominantly advocated social-justice issues and, while apart from ACL perhaps marginally favouring Labor, were more often critical of both major parties for their inattention to their concerns.

But it turned out not to be a campaign in which support for the major parties turned on religion. To begin with Labor's Rudd and Gillard were both acceptable to the religious lobby. Gillard did receive some initial awkward negative publicity about her beliefs. But later both Abbott and Gillard softened their stances in order to build a more appealing centrist image.

The target of the religious lobbyists, as it had been in 2007, then became the Greens-regarded objectively as the most secular of the Australian political parties. Both Pell and the ACL targeted them on a range of issues, such as marriage, education and euthanasia, while they recognised the virtues of the Greens in other areas such as refugees and climate change.

The overall impact of the religion factor was probably slight, but in policy terms the religious groups did win concessions, including extensions of financial support for school chaplains and for private schools. The Greens polled exceptionally well despite the religious opposition to them. Their most contentious candidate, Lee Rhiannon, was elected to the Senate in New South Wales, though with the lowest Greens Senate vote nationwide.

The smaller religious parties had one surprising success. Fielding (2.64 per cent) failed in his bid for re-election in Victoria, but he was replaced with the DLP candidate, John Madigan, a blacksmith from Ballarat, who polled 2.34 per cent (Zwartz 2010). Family First went much closer to winning in South Australia where former Liberal candidate Bob Day (4.09 per cent) ran a well-funded 
personal campaign. The anti-religious parties, though unsuccessful, made their mark, too. The Sex Party, for instance, polled more than 2 per cent in a number of States.

The relationship between conservative religious groups and Gillard will be tested in the new Parliament on issues that the Greens will advance such as gay marriage and euthanasia, but so far Gillard has remained either opposed to or cautious about these parliamentary developments despite public debate and some Labor support (Maiden 2010).

\section{References}

Australian Catholic Bishops' Conference. 2010. 'Make your vote count say Catholic bishops'. Canberra: Australian Catholic Bishops' Conference.

Australian Christian Lobby (ACL). 2010. Web site: <australianchristianlobby. org.au/>. Canberra: Australian Christian Lobby.

Australian Development Strategies. 2008. Profile of the 2007 Australian Election. Brisbane: Australian Development Strategies.

Brennan, Frank. 2010. 'Why a conscientious Christian could vote for the Greens'. Eureka Street, 10 August.

Burchell, David. 2010. 'Power not a God-given right'. The Australian, 10-11 July.

CathNews. 2010a. 'Look at politicians' ethics not just faith: Anglican Archbishop'. CathNews, 2 August.

CathNews. 2010b. 'Greens closer to Christian ideals than Cardinal Pell, says Bob Brown'. CathNews, 9 August.

Elder, Stephen. 2010. 'A vote for the Greens is a vote against Catholic education'. Eureka Street, 12 August.

Fitzgerald, Ross. 2010. 'Welcome to the house of fun'. The Australian, 27 August.

Gleeson, Kate. 2010. Tony, Tony, Tony! Abbott and abortion. Paper to Australian Political Studies Association Annual Conference, Melbourne.

Macklin, Robert. 2007. Kevin Rudd: The biography. Melbourne: Viking.

McLennan, David. 2010. 'More flock to the fold under atheist Gillard'. The Canberra Times, 8 August. 
Maiden, Samantha. 2010. 'Changing dying laws difficult, says PM'. The Australian, 22 September.

Manning, Hayden and Warhurst, John. 2005. 'The old and new politics of religion'. In Marian Simms and John Warhurst (eds), Mortgage Nation: The 2004 Australian election. Perth: API Network, 263-270.

Mullins, Michael. 2010a. 'Gillard's atheism belongs in the closet'. Eureka Street, 2 August.

Mullins, Michael. 2010b. 'Atheist "real Julia" courts Christian vote'. Eureka Street, 9 August.

Pearson, Christopher. 2007. 'Rudd's dog whistle days'. The Australian, 8-9 December.

Quinlan, Frank. 2010. 'Inside Canberra's Catholic lobby'. Eureka Street, 18 August.

Rudd, Kevin. 2006. 'Faith in politics'. The Monthly, October.

Sharp, Ari. 2010. 'Call for PM to outline her inspiration'. Sydney Morning Herald, 29 June.

Smith, Rodney. 2009. 'How would Jesus vote? The churches and the election of the Rudd Government'. Australian Journal of Political Science 44.

Stephens, Scott. 2010. 'The Prime Minister puts her faith in chaplaincy'. $A B C$ News, 10 August.

Stockman, David 2010. 'No change to stance on gay marriage'. The Canberra Times, 1 July.

Stuart, Nick. 2009. 'Mixed in a miracle and a mess'. The Canberra Times, 22 December.

The Australian. 2010. 'The Opposition comeback at the August election forces a reassessment of the religion issue'. [Cut and Paste], The Australian, 13 September.

Warhurst, John. 2007. 'Religion and politics in the Howard decade'. Australian Journal of Political Science 42(1) (March): 19-32.

Warhurst, John. 2010a. 'Religion'. Australian Cultural History 28(1) (April): 31-37.

Warhurst, John. 2010b. 'Pell, Brown in unholy strife'. The Canberra Times, 12 August. 
Warhurst, John. 2010c. The faith of Australian prime ministers. Presented to Australian Political Studies Association Annual Conference, Melbourne.

Young, Graham. 2010. 'It's real man versus metro man in the new culture wars'. Online Opinion, 2-3 January.

Zwartz, Barney. 2010. 'Ballarat blacksmith forges ahead with nod to DLP heroes'. The Age, 23 August. 